\title{
Leadership Failure and Acute Youth Unemployment in Nigeria
}

\author{
U.C. Okolie, M.D. Igbini \\ Delta State University \\ P.M.B 1, Abraka, Nigeria
}

\begin{abstract}
The history of Nigeria is tainted with the absence of good moral and ethical values in the conduct of the ruling elites; this has adversely affected economic growth and development. Continued poverty reinforced by acute youth unemployment is a barrier to Nigeria's quest for consolidating her democracy. A society of beggars, parasites and bandits cannot develop. Youth unemployment has been and is still a major problem in Nigeria. The statistics is staggering despite the political clamours against unemployment. The root of this problem originated in the visionless, selfish, mediocre, tribalistic and opportunistic small money-minded people masquerading as leaders who have continued to regenerate Nigerian political landscape over time. It is against this backdrop that this study examines the relationship between leadership failure and acute youth unemployment in Nigeria. A cross-sectional method was adopted and data was collected via a survey of three hundred (300) respondents in southsouth geopolitical zone of Nigeria using non-probability sampling technique. Data collected were analyzed using correlation and linear regression analysis with the aid of Statistical Package for Social Science (SPSS) version 21. The results of the study revealed that there is significant relationship between leadership failure and acute youth unemployment. As predicted, the study also showed that leadership failure exerts a positive and statistically significant impact on acute youth unemployment in Nigeria. On the basis of these findings, the study recommends among others that the government at all levels should empower the jobless youths through genuine empowerment schemes that would equip them to be self-employed and employer of labor, revamped agricultural development schemes to create job opportunities for the unemployed youths roaming about on the Nigeria streets and the actualization of youth empowerment would be impossible if the war against corruption is not intensified.
\end{abstract}

Keywords: leadership failure, youth unemployment, poverty, insecurity

\section{Introduction}

The Nigeria government remains distant from serving the interest of its people. Politics at the federal, state and local levels of the Nigerian Federation are dominated by the powerful mandarin who built vast patronage networks during the military days and who now use political office to expand these networks and their personal fortunes. The history of Nigeria is tainted with the absence of good moral and ethical 
values in the conduct of the ruling elites. This has adversely affected economic growth and development in Nigeria. Continued poverty, reinforced by acute youth unemployment is a barrier to Nigeria's quest for consolidating her democracy. A society of beggars, parasites and bandits cannot develop. The increase rate of sectarian violence, crimes and terrorism are connected with unemployment [1]. Acute youth unemployment breeds a high rate of state insecurity which borders on ethnoreligious conflicts, indigenes and settlers divide, armed robberies, abductions, kidnapping and other criminal activities in Nigeria [2].

Acute youth unemployment has been and is still a major problem in Nigeria. The statistics is staggering despite the political clamours against unemployment. The root of this problem originated in the visionless, selfish, mediocre, tribalistic and opportunistic 'small money-minded' people masquerading as leaders who have continued to regenerate Nigerian political landscape since 1960. All the state youth empowerment programmes and other employment generating policies of successive administrations from 1960 to date have failed to achieve their founder's vision because of gross, mismanagement and rampant corruption which has deepened social crises of unemployment and increased idle youths who have recourse to militia groups to gain livelihood by aligning with a political party to perpetrate violence. Thus, the present predicaments of Nigerian state can be explained from the lenses of leadership failure. Against the foregoing, this study empirically examines the relationship between leadership failure and acute youth unemployment in Nigeria.

\section{Statement of Problem}

Democracy has experienced stunted growth in Nigeria due to poor leaders with reactionary intent, bereft of developmental ideologies, retrogressive leadership style and bad governance. Nigerian leadership has acquired immunity of irresponsible rulership through reckless mismanagement of public funds, misplacement of peopleoriented needs, intolerable and sit-tight and power-drunk syndrome. Nigerian is crises ridden due to insatiable political disposition of the leadership. Since Nigeria gained her political independence in 1960, the political leaders are highly corrupt, incompetent, ineffective and self-centered. Arising from those qualities of leaders, Nigeria's vast economic potentials have been emasculated with serious implications for acute youth unemployment. Nigeria as a nation has no doubt underdeveloped the youths, the consequence of this abject neglect of the Nigerian youths on national insecurity and economic development are best imagined. A trip to all the crannies and corners of the Nigerian cities will reveal the pathetic condition of the youths as a result of systemic disempowerment [3].

Unemployment is a global phenomenon whereby an eligible workforce of the nation is deprived in the service of the country. It is not only a serious economic issue but also has implications that affect almost all countries and all people either directly or indirectly [1]. According to Orhero [4. P. 91], poverty and unemployment "causes social disquiet and they are the harbinger of the spate of crimes, perennial youth unrest as well as unstable socio-economic structure that have bedeviled several nations. In nigeria today, poverty and unemployment carry 
with them a number of attendant social, political, economics, psychological and security challenges". Thus, the rising spate of crimes and terrorism across the length and breadth of the country are connected with poverty and acute youth unemployment. As observed by Nwagbosa [5], the failure of successive governments in Nigeria to address challenges of poverty, unemployment and inequitable distribution of wealth among ethnic nationalities is one major causes of insecurity in the country.

Existing studies on unemployment in Nigeria theoretically accounted for the nexus between unemployment and insecurity, unemployment and poverty, and the effect of governmental attitude and policies on unemployment and security in Nigeria., however, no study have empirically examines the relationships and the effect of leadership failure on acute youth unemployment in Nigeria. This study was undertaken to fill this obvious research gap by analyzing the relationship between leadership failure and acute youth unemployment in Nigeria.

\section{Review of Related Literature Concept of Leadership}

Leadership is important to demonstrating better-quality governance which enhances societal development, because it is a process of influencing the actions of a structured group towards the setting and attainment of goals. It is "the ability to guide, direct or influence people. A leader ought to have an honest understanding of who he/she is, what he/she knows and what he/she can do. It is all about creating a way for people to contribute to making something extraordinary happen. It is also about "sacrifice for the common good" [6. P. 105]. According to Weihrich and Koontz [7], the essence of leadership is followership. In other words, it is the willingness of people to follow that makes a person a leader. Moreover, people tend to follow those whom they see as proving a means of achieving their own desires and needs. Therefore, leadership was conceived by Weihrich and Koontz [7. P. 490] as "influence, that is, the art or process of influencing people so that they will strive willingly and enthusiastically toward the achievement of group goals".

Leadership according to Achebe [8], is a process of social influence in which one person can enlist the aid and support of others in the accomplishment of a common task. This definition is substantiated against the backdrop that "everything rises and falls on leadership and every endeavour you can undertake that involves other people will live or die depending on leadership". [9: 1]. The common characteristic of a leader is the ability to inspire and stimulate others to achieve worthwhile goals. The individuals who can accomplish these important deeds practice leadership.

For further understanding of the concept of leadership, it is pertinent also to look at the qualities of a good leader. Joseph and Agbaje [10] enumerated these qualified to have include honesty, commitment, ability to inspire others, ability to delegate, sense of humour, creativity, confidence and positive attitude. Maxwell [11] reinforces that a good leader must have character, charisma, committed, communicate with followers, competence, courage, discernment, focus, possess positive attitude, generosity, good initiative, have passion, can solve problems, 
listen to followers, have good relationships with followers, take responsibility, have self-discipline, must be a servant, a teacher and have vision. These qualities are lacking in Nigerian leaders.

\section{Leadership Failure in Nigeria}

A failed, corrupt and inept leadership coupled with inclement domestic sociopolitical environment have plunged development performance in Nigeria into the abyss. Development is no longer what the people desire, but what the creditor nations and international financial institution dictate. One of the major factors responsible for political instability and the rising spate of insecurity is the failure of the political elites to sufficiently adhere to the basic tenets of democracy and constitutionalism [12]. As Harriman [13. P. 2] has rightly noted, this situation "has given rise to abuse of power, brazen corruption, disregard for due process and the rule of law, intolerance of political opposition, abuse of the electoral process and the weakening of institutions". This contradicts the tenet of governance, which presupposes the process of social engagement between the rulers and the ruled in a political community $[14 ; 15]$.

It is instructive to note that the leadership problem in the Nigerian polity was a manifestation of the dysfunctional pattern of the years of military interregnum. The leadership pattern in Nigeria lacks the necessary focus capable of instilling national development. Our leaders are dull, selfish, indiscipline, undedicated to duty, incompetent and highly corrupt. In analyzing the plethora of leaders that have bestrode the country's political landscape, Ebegbulem [16] and Nwagwu [17], revealed that political leaders in Nigeria lean heavily on ethnicity and religion in tandem with their colonial heritage that borders on mistrust, tribal antagonism, religious intolerance and instinct of political domination, this unfortunate trend is blended with high profile corruption by all the three arms of government (i.e., the executive, legislature and judiciary), fostering nepotism and bureaucratic ineptitude. According to Anazodo, Igbokwe-Ibeto and Nkah [18], Nigerian underdevelopment crisis is the effect of poor quality of government, absence of transparency and accountability, inefficiency of the workforce, corrupt and crippling bureaucracy and weak legal system. Anyiwe and Aigbokhaevbolo [19] argued that Nigerian leaders have brazenly mismanaged both human and material resources at their disposal. They further argued that in spite of these abundant resources, the rate of poverty, unemployment and mortality is very high. The country is vulnerable to infectious diseases like Ebola virus, Lassa fever, Polio, missiles, leprosy, tuberculosis, epidemic and influenza.

Nigerian politicians ride on ethno-religious sentiment to attain political relevance. Nigeria is a flashpoint for ethnic-based political leadership tussle and fanatic religious coloration in conflict brewing; it suffered stunted growth in its weak efforts to harness the human and material resources to foster good governance. Our political leaders have no vision, mission and passion. Visionless leadership has manifested in ethnic chauvinism, tribalism and nepotism in Nigeria. As Dowden [20] has rightly observed, without positive vision and passion, 
leadership will not succeed. It is vision that keeps the leader on track, while passion fuels the vision and makes it succeed. Take example of Singapore and Botswana in which by 1964 were also struggling as young nations, Singapore was and still is a multi-lingual, multi-cultural and multi-religious society, but its leaders did not see that as a barrier for nationhood; they rather believed that a fair and even-handed policy would get the people to live peacefully together and remain united [21]. Also, in Botswana, most of the credit was given to the leadership, which, since independence in 1966, has designed and fostered the conditions of governance that have ensured stability and socio-economic progress [21]. Thus, their leaders were vision oriented; they pursued their goals with all sincerity and passion and today Singapore has moved from third world to first.

From 1960 to the present democratic dispensation, Nigeria has been struggling with leadership dearth prominently found in the character of our political elites. Nigerian political leaders have found politics as a quick way of becoming very rich and economically powerful people, as a result of this; they explore all corrupt avenues to siphon, misappropriate and embezzle public funds into their own personal coffers. The extensive research work on corruption in the 1990s led to a worldwide shared view of it as a 'cancer' to be combated in both developed and developing countries. With specific reference to developing countries, especially Nigeria, there is strong evidence that corruption undermines development efforts, distorts the composition of government expenditure, reduces expenditure on operations and maintenance, lowers the quality of public infrastructure and service delivery, reduces government revenues, lowers incentives to private investment, undermines legitimacy and credibility of the state, influences outcomes of the legal and regulatory processes, violates the social and economic rights of the poor and the vulnerable and erodes the moral fabric of society [23]. In June 2018, World Poverty Clock listed ten most poor countries in the world with Nigeria emerging first with the rates of 86.9 million with great implications on employment. The rate of poverty in Nigeria can simply be explained against the backdrop of institutionalized corruption as observed by Dowden [20], thus, all its institutions-the civil service, the law, hospitals, schools, the army, police, business, etc, had become so corrupt that although Nigeria looks like a functioning state, it is just a shell. It still holds the shape of a nation from the outside, but within, corruption has become the institution.

More so, another dimension of leadership dearth in Nigeria is lack of political will and commitment for effective service delivery. Our political leaders have shown low level of patriotism which is love for one's country and willingness to sacrifice for it. Instead of serving the country with all sense of commitment, they placed nepotism and self-egotism at the altar of selfless service; as a result, there is high level of indiscipline and lack of self-control. Our leaders who are expected to be the first to keep and uphold the laws of the land break them with impunity. These attributes of Nigerian leaders have held the country at stand still since Nigeria gained her political independence in 1960 with serious implications for nation-building and development, therefore, leadership failure in the context of this study means the inability to achieve goals and mission. The reasons for leadership failure include mismatch between needs and programmes, poor attitude, blindness to reality, not 
valuing diversity, over-confidence, failure to listen to feedback from others, having wrong expectations, failure to communicate a vision, ignoring relationship building, failure to embody values and create the environment with which things can be accomplished and lack of social skills, leaders also fail when they care little about the consequences of their actions or followers as the case in Nigeria.

\section{Youth Unemployment}

Youth occupy a prominent place in any society. They are one of the greatest assets any nation can have. Apart from being the leaders of tomorrow, they outnumber the middle-aged and the aged [33]. The National Youth Development Policy [25] asserts that the youth are the foundation of a society; their energies, inventiveness, character and orientation define the pattern of development and security of a nation. Through their creative talents and labour power, a nation makes giant strides. The youth are a particular segment of the national population that is sensitive, energetic and active and the most productive phase of life as citizens. The youth are also most volatile and yet the most vulnerable segment of the population in terms of socio-economic, emotion and other aspects [26; 27]. According to Lamido [28], Youth unemployment is generally caused by improper orientation of the youths, absence of policy on social welfare, societal attitude towards vocational and technical education and inadequate teaching facilities.

Unemployment is synonymous with poverty; this is because when someone has nothing to do for a living, he/she becomes very poor in every ramification. Nwagwu [17. P. 34] posits that poverty is "a product of unemployment, inequality and economic marginalization. The jobless youths are frustrated due to inequality and economic deprivation that have rendered them unemployed. Thus, any individual deprived of the basic wherewithal cannot participate effectively in a democratic process. A poor person is therefore not a fully-fledged social individual, as he/she lacks the basic freedom to engage in the life he/she enjoys. It is important to note that about $90 \%$ of the Nigerian populations are estimated poor, is there any wonder why the society is Chaotic? [29]. According to International Labour Organization [30], unemployment occurs when people are without jobs and they have sought work within the past five weeks. Also, International Labour Organization [30] defines unemployed as numbers of the economically active population who are without work, but available for and seeking work, including people who have lost their jobs and those who have voluntarily left work. According to Adebayo, 1999 cited in Akwara, Akwara, Enwuchola, Adekunle and Udaw [31], unemployment occurs when the labour force wish to work but cannot get jobs.

The unemployment rate is a measure of the prevalence of unemployment and it is calculated as a percentage by dividing the number of unemployed individuals by all individuals currently in the labour force. Thus, unemployment is defined as the proportion of labour force that was available for work but did not work in the week preceding the survey period for at least 39 hours [3]. In Nigeria today, the rapid increase in the country's unemployment rate has become a major sources of worry, several school leavers and adults are either finding it difficult to secure 
employment or are laid off work for one reasons or the other. It is no longer about going to school and graduating or learning a trade, but about how to face the reality of graduating and joining the brigade of the unemployed with little hope of what the future holds [4]. The youth unemployment rate in Nigeria refers to the percentage of the unemployed in the age group of 15 to 44years as compared to the total labour force. Youth unemployment rates are often higher than overall unemployment rates, which is true in Nigeria as well. The table below (table 1) shows the youth unemployment rate from 1999 to 2019.

Table 1

\section{Youth Unemployment Rate in Nigeria}

\begin{tabular}{|c|c|}
\hline Year & Percentage \\
\hline 1999 & 9.14 \\
\hline 2000 & 8.9 \\
\hline 2001 & 9.15 \\
\hline 2002 & 9.24 \\
\hline 2004 & 14.80 \\
\hline 2005 & 13.40 \\
\hline 2006 & 11.90 \\
\hline 2007 & 13.70 \\
\hline 2008 & 14.60 \\
\hline 2009 & 14.90 \\
\hline 2010 & 19.70 \\
\hline 2011 & 23.90 \\
\hline 2012 & 24.90 \\
\hline 2013 & 25.20 \\
\hline 2014 & 25.43 \\
\hline 2015 & 36.07 \\
\hline 2016 & 49.03 \\
\hline 2017 & 57.59 \\
\hline 2018 & 59.45 \\
\hline 2019 & 62.83 \\
\hline
\end{tabular}

Source: NISER, 2020 [31].

The table above indicates that the issue of youth unemployment is critical in Nigeria. Unemployment has become a major problem bedeviling the lives of youth, causing frustration, dejection and dependency on family members and friends, who also have their own problems to contend with. Youth's unemployment in Nigeria is a consequence of several factors; one major factor is that of population growth. Nigeria has continued to experience high rate of population growth. Leadership failure is another major factor responsible for acute youth unemployment in Nigeria. Lack of employable skills due to inappropriate school curricula is another factor contributing to the rising youth unemployment. Yet another factor is the perception of policymakers and the youth themselves about employment. To the policymakers and the youth, employment means a job with salary and working for someone else. It is this perception that has continued to influence the tertiary 
educational institutions in Nigeria that provide skills and training. Based on this, Curricula and training programmes are generally tailored towards preparing young people for formal sector jobs. Since these jobs do not exist, there is often a mismatch between the skills possessed by the job seekers and the available jobs.

In fact, education system in Nigeria has its liberal bias which indeed over supplies the labour market with graduates who do not possess the skills required by many employers of labour in Nigeria. Today, many graduates in Nigeria lack entrepreneurial skills to facilitate self-employment [33]. Among other factors responsible for acute youth unemployment include poor governance, ineffective targeting of the poor resulting in resources being thinly spread among competing projects, overlapping of functions, poor coordination and lack of sustainable measures [34]. According to the National Bureau of Statistics [35], youth people aged between 15 and 24 years accounted for $63.4 \%$ of unemployed people while those aged between 25 and 44 years accounted for $57.6 \%$.

\section{Consequences of Acute Youth Unemployment}

The increasing level of youth unemployment in Nigeria is one issue that has been responsible for the resurgence of militia groups in the country. Youth unemployment has been identified as one of the major causes of social vices including armed robbery, political thuggery, destitution, prostitution, kidnapping and hostage-taking [1]. Indeed, acute youth unemployment in Nigeria is responsible for the spate of kidnappings, the marauding herdsmen militancy, armed robberies, abductions, Boko Haram insurgency, the new face of militancy in the Niger Delta and other forms of violent crimes. Unemployment has also encouraged increasing feminization of poverty among young women, which has encouraged prostitution as a means of survival and leads to trafficking of young ladies across international borders with transnational security implications [31]. Furthermore, the negative consequences of acute youth unemployment include poverty; psychological problems of frustration, depression, hostility, murder and all manner of social delinquent behaviours. Thus, acute youth unemployment in Nigeria today has contributed to the high rate of poverty and insecurity of life and property. With the growing rate of unemployment and underemployment of the youths, Nigeria has suffered enormous loss in terms of growth and development opportunities which would have engaged their wasteful human capital [17].

\section{Youth Empowerment Programmes}

The existing literature reveals that successive Nigerian government has played vital roles in providing solutions to unemployment and poverty alleviation. But in spite of the myriad policies and programmes initiated by Nigerian government such as Operation Feed the Nation (OFN), Green Revolution Directorate of Food, Roads and Rural Infrastructure (DFRRI), Better Life for Rural Women (BLRW), Family Support Programme (FSP), People Bank (PB), The Introduction of Privatization, Liberation and Deregulation of the Economy, National Economic Empowerment and Development Strategy (NEEDS), Subsidy Re-investment and Empowerment Programme (SURE-P), National Directorate of Employment (NDE), N-Power, Presidential Youth Empowerment Scheme (P-YES) and other poverty reduction 
programmes from 1999 to date have failed to achieve their founder's vision. Consequently, the rank of the unemployed and idle youths increased the number and people who had recourse to ethnic formations to gain livelihood, define their identity and promote ethnic nationalism. This is the hopeless situation we found ourselves due to bad leadership exercised through bad governance. In Nigeria today, one of the major inducements to insecurity challenges is high rate of unemployment, especially among the youths. For instance, no fewer than 8 million youths are jobless in Nigeria, while 2.7 million graduates enter the labour market every year. Since the primary need of man is food, it is not surprising that the army of unemployed and jobless Nigerian youths resort to self-help in the form of kidnapping, armed robbery, prostitution as well as making themselves available to be engaged as ready tools for destabilization and insecurity. This is based on the aphorism that 'an idle mind is a devil's workshop' and 'a hungry man is an angry man'.

\section{Leadership Failure and Acute Youth Unemployment in Nigeria}

The unemployed youths (educated and uneducated alike) are frustrated by the poor governance of the political elite. It is the primary responsibility of all levels of government to harness and husband the state resources; and create job opportunities for the teaming unemployed population, protect lives and properties and ensure good governance at all levels. Youth unemployment rate in Nigeria is very high in spirit of the favourable economic potentials for employment generation in the country, such as rapid increases in government revenues, windfalls from oil proceeds and the appreciable rise on foreign reserves. Apart from the serious adverse effect of corruption on the economy, faulty and unfavourble economic policies of the government since 1960 to date have acted as disincentives to employment creation (such as high interest and exchange rates, poor infrastructures, import tariff, etc.) which have dwindled the employment absorptive capacity of the private sector; and non-investment of these resources in employment generation are responsible for sustaining youth unemployment in the Nigeria economy [17].

The political leaders in Nigeria have failed the Nigerian state in spite of the huge amount of money crude oil has given to the country. Despite the long period of oil exportation, Nigeria has nothing to show with soaring rates of youth unemployment and poverty [36]. Similarly, Salawu [37] linked failed state to mass poverty, illiteracy and unemployment, he further posits that poverty and unemployment inevitably increase the number of people (youths) who are prepared to kill or be killed for a given course at token benefit. To state that there is high level of youth unemployment in Nigeria is stating the obvious. This is because youth unemployment had reached an alarming stage. The root of this problem is leadership failure. As former president Olusegun Obasanjo argued, "When you see a poor country, look out for the form of governance there, then you will observe leadership challenges". He is among those who believed that leadership dearth in Nigeria had robbed it of meaningful development and has become a clog on the nation's wheel of progress. Obasanjo affirmed that "we have so many Nigerians, but there are not many good leaders in Nigeria". From political leadership to traditional, commerce to education and down to the family level, the ideal form of leadership is nowhere to be found [38]. 
According to Anazodo et al. [18: 42], one of the major challenges facing Nigeria and other developing areas of the world is how to create a stable political and socioeconomic environment for policies and programmes to be implemented. The issue of getting the right leadership to fight corruption and propel good governance has been a recurring decimal in Nigeria and Africa in general. Once the enabling environment is created, it becomes very easy for the people to confront and resolve challenges facing them by using resources within their environment to create a condition of life where each stage is progressively better than the preceding one. However, this is not the case in Nigeria due to corruption and bad governance". They further noted that the reverberation effect of the failure of leadership, corruption and bad governance are visible and being felt across all sectors and segment of the Nigerian society. Unemployment and employment for cash, insecurity, crude oil thefts, crisis in education, dearth of infrastructures such as health services, transportation, accommodation, communication, medication, etc are all common features in Nigeria. Also, Adegoke's [1] study in Lagos revealed that there is a relationship between government attitude and policies and youth unemployment in Nigeria.

\section{Theoretical Framework}

In our attempt to place this study in its proper perspective, the need for a theoretical framework of analysis is very fundamental. The theoretical framework of analysis adopted in this study is the Frustration-Aggression theory. The frustration-aggression hypothesis formulated by Dollard, Doob, Miller, Mowrer and Sears [39] has the central premise that the occurrence of aggressive behaviour always presupposes the existence of frustration. According to them, frustration produces instigation to a number of different types of responses, one of which is an instigation to some of aggression, expatiating on the above postulation, Okolie et al. [2] submit that, given the requisite conditions, individuals or groups who feel frustrated in the attainment of their desires and demands often react by direct aggressive bahaviour at what is perceived as being responsible for depriving or thwarting those desires as a substitute, they further posit that it is not utter lack but unfulfilled hopes and expectations that engender violent crimes. Fundamentally, the overall policy goal of National Youth Policy (NYP) is to provide and appropriate framework that will promote the enjoyment of fundamental human rights and protect the health, social, economic and political well-being of all young (men and women) in order to enhance their participation in the overall development process and improve their quality of life. It could be argued from the above vantage points that National Youth Policy and other empowerment programmes have not yielded results in curbing unemployment rate, but rather causing frustration and dependency on the part of the youths. The state of deprivation and frustration have driven youths to kidnapping, drug abuse, political thuggery, hostage-taking, prostitution, vandalization of oil pipelines, abduction, armed robbery and other criminal activities as options for idleness. In the final analysis, the relevance of the frustration-aggression theory is based on its ability to justify how frustration as a result of lack of employment opportunities has contributed to youth involvement in delinquent behaviour in Nigeria.

In line with the literature review, the following objectives and null hypotheses were formulated for the study. 


\section{Objectives of the Study}

Specially, the study sought to:

i. Examine the relationship between leadership failure and acute youth unemployment in Nigeria.

ii. Ascertain the extent to which leadership failure impact on acute youth unemployment in Nigeria.

\section{Hypotheses of the Study}

$\mathrm{H}_{1}$ : There is no significant relationship between leadership failure and acute youth unemployment in Nigeria.

$\mathrm{H}_{2}$ : Leadership failure does not have a significant impact on acute youth unemployment in Nigeria.

\section{Methodology}

\section{Research Design and Data Collection}

This study adopted a survey research design to determine the relationship and impact of leadership failure on acute youth unemployment in Nigeria and data was collected via a survey of 300 respondents in South-South geopolitical zone of Nigeria using non-probabilistic sampling techniques comprising of purposeful and convenience techniques. Thus, the instrument used for this study was researchers developed structured questionnaire, the questionnaire consisted of 22 items structured along a 5-points likert type scale which ranks responses on a scale of (1) strongly agree (SA) to strongly disagree (SD) (see table 2).

\section{Distribution of Questionnaire and Response Rate}

\begin{tabular}{|l|l|l|l|l|}
\hline S/N & South-South State & $\begin{array}{l}\text { Questionnaire } \\
\text { Distributed }\end{array}$ & $\begin{array}{l}\text { Questionnaire } \\
\text { Retrieved }\end{array}$ & $\begin{array}{l}\text { Percentage } \\
\text { Retrieved }\end{array}$ \\
\hline $\mathbf{1}$ & Delta & $\mathbf{5 0}$ & $\mathbf{4 7}$ & 15.7 \\
\hline $\mathbf{2}$ & Rivers & $\mathbf{5 0}$ & $\mathbf{4 4}$ & $\mathbf{1 4 . 7}$ \\
\hline $\mathbf{3}$ & Bayelsa & $\mathbf{5 0}$ & $\mathbf{4 6}$ & 15.3 \\
\hline $\mathbf{4}$ & Edo & $\mathbf{5 0}$ & $\mathbf{4 7}$ & 15.7 \\
\hline $\mathbf{5}$ & Akwa Ibom & $\mathbf{5 0}$ & $\mathbf{4 5}$ & $\mathbf{1 5 . 0}$ \\
\hline $\mathbf{6}$ & Cross rivers & $\mathbf{5 0}$ & $\mathbf{4 4}$ & $\mathbf{1 4 . 7}$ \\
\hline & Total & $\mathbf{3 0 0}$ & $\mathbf{2 7 3}$ & $\mathbf{9 1 . 1}$ \\
\hline
\end{tabular}

Source: Questionnaire Administered, 2020.

Out of the 300 copies of questionnaire administered, 273 were retrieved and analyzed given us a response rate of $91.1 \%$. Out of the 273 respondents, 149 were male and 124 were female respectively.

\section{Validity and Reliability of the Instrument}

The validity of the research instrument was ascertained by subjecting its initial draft to face validation by two experts in the department of political science, Delta State University, Abraka. The opinions and suggestions of these experts were used to modify and produce the final draft of the instrument. The research instrument also underwent reliability test conducted on 30 respondents in Delta 
State who also took part in the study, Cronbach Alpha method was used to establish the internal consistency of the items as shown in the table below (table 3).

Reliability Statistics of Variables

\begin{tabular}{|l|l|l|}
\hline Scale & No of items & Crobach's Alpha \\
\hline Leadership failure & 14 & .815 \\
\hline Acute youth unemployment & 8 & .837 \\
\hline
\end{tabular}

Sources: Researchers' Computation, 2020.

The results yielded a coefficient of 0.815 and 0.837 , which satisfied the general recommended level of 0.70 for the research indicators. Hence, researchers satisfied both the validity and reliability of the scale.

\section{Model specification}

Given that this study has one dependent variable, we formulate the model as shown below:

The model has the following mathematical functions:

$\mathrm{AYU}=\mathrm{f}(\mathrm{LF})$

Econometrically, the model was specified as:

$\mathrm{AYU}=\beta_{0}+\beta_{1} \mathrm{LF}+\varepsilon \mathrm{t}$

Where:

AYU = acute youth unemployment.

$\mathrm{LF}=$ leadership failure.

$\beta_{0}=$ Constant

$\beta_{1}=$ Coefficient and apriori sign of independent variable.

$\varepsilon \mathrm{t}=$ error term.

From the above, the apriori expectation of the parameter of the model was:

$\beta_{1}<0$

\section{Method of Data Analysis}

The data collected were analyzed using correlation and linear regression analysis with the aid of the Statistical Package for Social Science (SPSS) version 21.

\section{Results}

Correlation Matrix

\begin{tabular}{|l|l|l|l|}
\hline Variables & & $\begin{array}{l}\text { Leadership } \\
\text { Failure }\end{array}$ & $\begin{array}{l}\text { Acute Youth } \\
\text { Unemployment }\end{array}$ \\
\hline Leadership failure & $\begin{array}{l}\text { Pearson correlation } \\
\text { Sig. (2-tailed) }\end{array}$ & $\mathbf{1}$ & $\mathbf{. 8 4 1} * *$ \\
& $\mathrm{~N}$ & $\mathbf{. 0 0 0}$ \\
$\mathbf{2}$ & $\begin{array}{l}\text { Pearson correlation } \\
\text { Acute youth } \\
\text { unemployment }\end{array}$ & $\begin{array}{l}\mathbf{. 8 4 1} \\
\text { Sig. (2-tailed) }\end{array}$ & $\mathbf{. 0 0 0}$ \\
$\mathrm{N}$ & $\mathbf{2 7 3}$ & $\mathbf{1}$ \\
\hline
\end{tabular}

**Correlation is Significant at 0.05 levels (2-tailed)

Sources: Researchers' Fieldwork, 2020. 
Table 4 shows the correlation between leadership failure and acute youth unemployment in Nigeria. There exists a significant positive high correlation between leadership failure and acute youth unemployment $(r=.841, n=273$, \& $\mathrm{p}<0.05)$. This implies that leadership failure has a strong and positive relationship with acute youth unemployment in Nigeria. Therefore, the null hypothesis is rejected.

\section{Linear Regression Analysis}

Table 5

Model Summary ${ }^{b}$

\begin{tabular}{|l|l|l|l|l|}
\hline Model & $\mathbf{R}$ & $\mathbf{R}^{2}$ & Ad-R $^{2}$ & $\begin{array}{l}\text { Std. Error of } \\
\text { estimate }\end{array}$ \\
\hline 1 & .762 & .694 & .588 & .329 \\
\hline
\end{tabular}

i. predictors: (constant), leadership failure

ii. dependent variable: acute youth unemployment

Table 6

ANOVA $^{\mathrm{a}}$

\begin{tabular}{|c|c|c|c|c|c|c|c|c|}
\hline Model & $\begin{array}{l}\text { Sum of } \\
\text { square }\end{array}$ & Df & Mean & Coefficient & f-stat & Sig & D.W & Remark \\
\hline $\begin{array}{l}\text { Regression } \\
\text { Residual } \\
\text { Total }\end{array}$ & \begin{tabular}{|l|l|}
36.718 \\
19.445 \\
56.163
\end{tabular} & $\begin{array}{l} \\
269 \\
271\end{array}$ & $\begin{array}{l}4.129 \\
0.767\end{array}$ & 0.096 & 23.548 & $0.000^{b}$ & 1.927 & Sig \\
\hline
\end{tabular}

i. Dependent variable: acute youth unemployment

ii. Predictors: (constant), leadership failure

Sources: Researchers' fieldwork, 2020.

Table 6: shows $\mathrm{R}^{2}$ value of .694 which revealed that leadership failure independently account for $69.4 \%$ of the variation in acute youth unemployment in Nigeria. The coefficient of 0.096 further indicated that a one percent increase in leadership failure results in $9.6 \%$ increase in acute youth unemployment. The Fstatistics of 23.548 revealed that the model is statistically significant at 0.05 significant levels. The Durbin-Watson statistics of the model which shows 1.927 implies absence of serial autocorrelation in the regression analysis.

\section{Discussion of Findings}

The results amongst others showed that there is positive and strong relationship between leadership failure and acute youth unemployment in Nigeria. The finding is in agreement with Adegoke [1] study that revealed the relationship between government attitudes and polices and youth unemployment. As predicted, the study also revealed that leadership failure exerts a positive and statistically significant impact on acute youth unemployment in Nigeria. The finding is in agreement with Salawu [30; 36], Nwagwu [16], Adebowale (2015), Adegoke [1] and Orhero [4] view that leadership failure is responsible for youth unemployment and abject poverty in Nigeria. Thus, the ruling (political) class have failed Nigerians because they replaced the vision, policy and strategy, which should be the thrust of 
every leadership with transactions (contract award and other mundane moneyrelated activities), as each successive government took turns to prey on the nation's wealth, by using public power, resources, good will, utilities, instrument of abuse and personal gains. Thus, crimping the economy and exacerbating unemployment which creates abject poverty, hunger and frustration among the youths. Corroborating this unfortunate scenario, Anazodo et al. [17. P. 43], succinctly argued that "since the flag of political independence in 1960, Nigerian leaders and their regimes have been deeply engrossed in excessive acts of corruption and bad governance. All available means have been employed by Nigerian political leaders to 'grab' power including the blatant rigging of elections, manipulation of census figures, violence, thuggry, arson, vandalism, gangsterism, corruption, religious bigotry, regionalism, tribalism, ethic sentiments and acts of brigandage as witnessed in the utterances of some delegates in the 2014 national conference. Relegation of public interest, malpractices of all forms, crimes of every description, mendacity, lack of candour, readiness to cheat, grabbing, philistinism, ethnic and sectional inclinations are all the only game in town". All these have precipitated social dislocation, insecurity, violence, abject poverty, socio-economic and political instability and acute youth unemployment and underemployment.

\section{Conclusion and Recommendations}

The study has revealed through its perceived findings that leadership failure has a positive and strong impact on acute youth unemployment in Nigeria. Also, the relationship between leadership failure and acute youth unemployment was confirmed. In conclusion, Nigeria is the world sixth largest oil supplier and blessed with economic potentials, but majority of the Nigerian population live in narrow circumstances due to leadership failure and ranging endemic corruption. Since Nigeria return to democratic practice in 1999, youth unemployment has maintained speedy rise. It is, therefore, necessary to create jobs and generate employment for the unemployed Nigerian youths to give them sense of belonging and discourage them from engaging in the sundry acts of threat to security in the country. In Nigeria today, amidst high level of youth unemployment, there is incessant ethno-religious crises, Fulani herdsmen/farmers brouhaha, electoral and communal violence among others. Nigeria who supposed to be the giant of Africa becomes the sleeping giant whose economic and human power has been emasculated by unscrupulous politicians. This study strongly contented that our political leaders since Nigeria gained political independence in 1960 failed in their primary responsibility of harnessing and husbanding the state resources and creating job opportunities for the teaming unemployed population. This explains why armed robbery, kidnapping, terrorism, thuggery and sorts of social vices in Nigeria emanate from acute youth unemployment. Most importantly, addressing the breeding grounds of threats to security such as poverty, human rights violations and bad governance is a desideratum to put an end to the security issues in the country. Based on the empirical and theoretical findings of this study, the following policy recommendations were made: 
1. The government at all levels should intensity efforts to empower the jobless youths through genuine empowerment schemes that would equip them to be selfemployed and employer of labour, revamped agricultural development schemes to create job opportunities for the unemployed youths roaming about on the Nigerian streets and the actualization of youth empowerment would be impossible if the war against corruption is not intensified.

2. Poor quality of education, lack of efficient training and skills acquisition are negatively affecting the productive sector of our economy. Therefore, government at all levels should invest heavily on education and encourage research institutions for result oriented research-projects.

3. There is urgent need for participating nature of democracy to public agenda setting and decision-making as against that of exclusionary disposition of the military regime which may engender more economic growth, as it is disposed to the adoption of market forces which would bring competition to spur economic growth. This is capable of bringing to the barest minimum the perceptions of domination, marginalization, alienation or discrimination of one ethnic group against the other, which are quite detrimental to economic growth and development.

4. The government at all levels should create a conducive environment to enable the private sectors thrive and absorb many of the teeming jobless Nigerian youths.

\section{REFERENCES}

[1] Adegoke N. Youth Unemployment and Security Challenges in Nigeria. Asian Journal of Humanities and Social Studies. 2015; 3 (1): 13-22.

[2] Okolie U.C., Onyema A.O., Basey U.S Poverty and Insecurity in Nigeria: An Empirical Study. International Journal of Legal Studies. 2019; 6 (2): 247-261.

[3] Oduwole T.A. Youth Unemployment and Poverty in Nigeria. International Journal of Sociology and Anthropology Research. 2015; 1 (2): 23-39.

[4] Orhero A.E. Poverty, Unemployment and National Insecurity in Nigeria's Fourth Republic. International Journal of Legal Studies. 2019; 6 (2): 89-98.

[5] Nwagbosa C. Security Challenges and Economy of the Nigerian state (2007-2011). American International Journal of Contemporary Research. 2012; 2 (6): 244-258.

[6] Mahammad N., Danjuma D. Leadership and Critical Thinking: An Exploratory Search for a Nexus. Leadership and Complex Military Operation. Chukwuma C. (ed.). Kaduna: Nigerian Defence Academy; 2016.

[7] Weihrich H., Koontz H. Management: A Global Perspective. Singapore: McGraw-Hill; 1993.

[8] Achebe C. The Trouble with Nigeria. Enugu: Fourth Dimension Publishers; 1981.

[9] Bennies W. On Becoming a Leader. New York: Wesley; 1989.

[10] Joseph R.S., Agbaje T.A. Nigeria. Comparative Politics at the Crossroads. Kesselman M., Krieger J., Williams j. (eds.). Lexington, D.C: Health and Company; 1996.

[11] Maxwell J. The 21th Irrefutable Laws of leadership: Follows Them and People Will Follow You. New York: Thamos Nelson Publishers; 1998.

[12] Kew D. Nigeria. Countries at the Crossroads. Tatic S. (ed). New York: Freedom House; 2006.

[13] Harriman T. Is There a Future for Democracy in Nigeria? Text of a public lecture delivered at Dept. of International Development, Oxford University, Monday $5^{\text {th }}$ June, 2006. 
[14] Adejumobi S. Democracy, Good Governance and Constitutionalism in Africa. Governance: Nigeria in the World. Odion-Akhaine S. (ed). Lagos: Centre for Constitutionalism and Development; 2004.

[15] Fagbadebo O. Corruption, Governance and Political Instability in Nigeria. African Journal of Political Science and International Relations. 2007; 1 (2): 28-37.

[16] Ebegbulem J.C. Corruption and Leadership Crisis in Africa: Nigeria in Focus. Afroeuropa. 2009; 3 (2): 16-36.

[17] Nwagwu E.J. Unemployment and Poverty in Nigeria: A Link to National Insecurity. Global Journal of Politics and law Research. 2014; 2 (1): 19-35.

[18] Anazodo R.O., Igbokwe-Ibeto C.J., Nkah B.C. Leadership, Corruption and Governance in Nigeria: Issues and Categorical Imperatives. African Research Review. 2015; 9 (2): 41-58.

[19] Anyiwe A., Aigbokhaevbolo O. Democracy and Economic Growth: Statistical Evidence from Nigeria 1960-2002. Journal of Applied Science. 2006; 6: 257-265.

[20] Dowden R. Africa: Altered State, Ordinary Miracles. Great Britain: Portobello Books Ltd; 2009.

[21] Lee K.Y. From Third World to First. New York: Harper Collins; 2000.

[22] Lewin M. Botswana's Success: Good Governance, Good Policies and Good Luck. World Bank. 2018. URL: http://documents1.worldbank.org/curated/en/304221468001788072/ 930107812_201408253094647/additional/634310PUB0Yes0061512B09780821387450.pdf. Accessed: 10.04.2020.

[23] Good Governance: The IMF's Role. International Monetary Fund. Washington DC: IMF Publication; 1997.

[24] Onyekpe N. Managing Youth at Election: The Constitution. Journal of Constitutional Development. 2007; 1 (1): 76-87.

[25] Youth Unemployment Challenges. National Youth Development Policy. Abuja: NYDP publication; 2001.

[26] Anasi S.N. Curbing Youth Restiveness in Nigeria: The Role of Information and Libraries. Nigeria: Library philosophy of practice; 2010.

[27] Ajufo B.I. Challenges of Youth Unemployment in Nigeria: Effective Career Guidance as a Panacea. African Research Review. 2013; 7 (1): 307-321.

[28] Lamido S. Unemployment Fueling Insecurity in Nigeria. Punch Newspaper. 23.07.2013.

[29] Kwasau M.A. The Challenges of Democratic Consolidation in Nigeria's Fourth Republic. European Scientific Journal. 2013; 9 (8): 181-192.

[30] Gender and Youth Migration Convention. International Labour Organization. Geneva: ILO publication; 1982.

[31] Akwara A.F., Akwar N.F., Enwuchola J., Adekunle M., Udaw J.E. Unemployment and Poverty: Implications for National Security and Good Governance in Nigeria. International Journal of Public Administration and Management Research. 2013; 2 (1): 1-11.

[32] NISER Analysis and Design of Safety Nets and Capacity Empowerment Programmed for Unemployed Youths in Nigeria. 2020. URL: htt://www.niser.com. Accessed: 16.04.2020.

[33] Oladele P.O., Akeke N.I., Oladunjoye O. Entrepreneurship Development: A Panancea for Unemployment Reduction in Nigeria. Journal of Emerging Trends in Economics and Management Sciences. 2011; 2 (4): 257-256.

[34] Musari O. Challenges of Youth Unemployment in Nigeria: Major Causes of Social Vices. 2009. URL: http://www.sachajournals.com. Accessed: 18.04.2020.

[35] Unemployment in Nigeria. National Bureau of Statistics. Abuja: The NBS publication; 2018.

[36] Ogundiya I.S. Democracy and Good Governance: Nigeria's Dilemma. African Journal of Political Science and International Relation. 2010; 4 (6): 201-208. 
[37] Salawu B. Ethro-religious Conflicts in Nigeria: Casual Analysis and Proposals for New Management Strategies. European Journal of Social Sciences. 2010; 3 (2): 63-78.

[38] Alechenu J. Quest for Good Leadership in Nigeria. The Punch Newspapers. 23.07.2013.

[39] Dollard J., Doob L., Miller N.E., Mowrer O.H., Sears R.R. Frustration and Aggression. New Haven, C.T.: Yale University press; 1939.

\title{
Article history:
}

The article was submitted on 10.05.2020.

The article was accepted on 01.06.2020.

Научная статья

\section{Провал руководства и проблема безработицы среди молодежи в Нигерии}

\author{
У.Ч. Околе, М.Д. Игбини \\ Государственный университет Дельта \\ P.М.В 1, Абрака, Нигерия
}

\begin{abstract}
Аннотация. История Нигерии омрачена недостатками моральных и этических ценностей в поведении правящих элит, что отрицательно сказалось на экономическом росте и развитии. Продолжающаяся нищета, усугубляемая острой безработицей среди молодежи, является препятствием на пути к укреплению демократии в Нигерии. Общество паразитирующих нищих и бандитов не может развиваться. Безработица среди молодежи была и остается основной социальной проблемой в Нигерии. Несмотря на политические протесты против безработицы, негативная в стране статистика все еще ошеломляет. Автор уверен, что корень этой проблемы кроется в политике недальновидных, эгоистичных, посредственных, трайбалистически и оппортунистски настроенных лидеров, которые формируют нигерийский политический ландшафт. Именно исходя из этого в исследовании рассматривается связь между провалами и неудачами руководства и острой безработицей среди молодежи в Нигерии. В основу исследования легли данные, собранные путем опроса трехсот респондентов в южной Нигерии с использованием метода выборки без вероятности. Собранные данные были проанализированы с использованием корреляционного и линейного регрессионного анализа с помощью статистического пакета для социальных наук (SPSS. Версия 21). Результаты исследования показали, что существует значительная связь между провалами руководства и острой безработицей среди молодежи. Как и предполагалось, исследование также показало, что недееспособность руководства оказывает негативное и статистически значимое влияние на уровень безработицы среди молодежи в Нигерии. На основании этих выводов авторами рекомендуется, чтобы правительство на всех уровнях предоставляло возможности безработным молодым людям заниматься индивидуальной трудовой деятельностью и трудоустройством путем реального расширения их прав и возможностей, пересмотреть схему развития сельского хозяйства с целью создания возможностей трудоустройства для безработных молодых людей, сегодня бесцельно бродящих по улицам Нигерии. Расширение прав и возможностей молодежи также невозможно без усиления борьбы против коррупции.
\end{abstract}

Ключевые слова: провал руководства, лидерство, безработица среди молодежи, бедность, отсутствие безопасности, коррупция, Нигерия 


\section{История статьи:}

Статья поступила в редакцию: 10.05.2020.

Статья принята к публикации: 01.06.2020.

\section{Информация об авторах:}

Околе Уго Чакс - аспирант кафедры политических наук, государственный университет Дельта (Нигерия) (ORCID ID: 0000-0002-0448-2938) (e-mail: ugookolie3@gmail.com).

Игбини Мевайероре Даниэль - доктор политических наук, независимый исследователь (Нигерия) (ORCID ID: 0000-0002-3119-3891) (e-mail: igbinidaniel@gmail.com).

\section{Information about the authors:}

Ugo Chuks Okolie - PhD Student of the Department of Political Sciences, Delta State University (Nigeria) (ORCID ID: 0000-0002-0448-2938) (e-mail: ugookolie3@gmail.com).

Mevayerore Daniel Igbini - PhD in Political Science, Independent Researcher (Nigeria) (ORCID ID: 0000-0002-3119-3891) (e-mail: igbinidaniel@ gmail.com).

\section{Для цитирования:}

Okolie U.C., Igbini M.D. Leadership Failure and Acute Youth Unemployment in Nigeria // Вестник Российского университета дружбы народов. Серия: Государственное и муниципальное управление. 2020. Т. 7. № 3. С. 254-271. DOI: 10.22363/2312-8313-2020-7-3-254-271

\section{For citation:}

Okolie U.C., Igbini M.D. Leadership Failure and Acute Youth Unemployment in Nigeria. RUDN Journal of Public Administration. 2020; 7 (3): 254-271. DOI: 10.22363/23128313-2020-7-3-254-271 